We thank Merck, Sharp and Dohme for their generous supply of $\mathrm{D}$-penicillamine.

M. E. Nimni

NANCY GERTH

L. A. Bavetta

Department of Biochemistry and Nutrition,

School of Dentistry,

University of Southern California,

Los Angeles.

' Nimni, M. E., and Bavetta, I. A., Science, 150, 905 (1965).

${ }^{2}$ Nimni, M. E., Biochim. Biophys. Aeta,111, $576(1965)$.

${ }^{3}$ Piez, K. A., Lewis, M. S., Martin, G. R., and Gross, J., Biochim. Biophys. Acta, 53, 596 (1961).

' wilson, J. E., and du Vigneaud, V., J. Biol. Chem., 184, 63 (1950).

'Nimni, M. E., and Bavetta, L. A., Proc. Soc. Exp. Biol. and Med., 117, 618 (1964).

"Nimni, M. E., de Guia, E., and Bavetta, L. A., J. Invest. Dermatol., 47, 156 $(1966)$.

\section{Double-disc Electrophoresis of Proteins}

GEL electrophoresis in discontinuous buffer systems ${ }^{1}$ is a valuable method of examining dilute protein solutions. By selecting $p \mathrm{H}$ conditions it is possible to concentrate and then separate either cationic or anionic proteins, but only in separate analyses. Thus, the tris-glycine system can be used, in which the running $p \mathrm{H}$ is $\mathbf{9 . 5}$ and most proteins migrate as anions ${ }^{1}$. The usual cationic proteins will either not migrate or will move backwards as a large zone equal in size to the origin. Conversely, an acidic system, such as $\beta$-alanine-acetate, may be chosen in which cationic proteins migrate at $p \mathrm{H} 4 \cdot 0$ (ref. 2), but in this case the anionic proteins are lost to further analysis. Apart from the loss of time and research material necessitated by separate analyses, thore is an unavoidable ambiguity about the direction of migration of a particular protein, because it is quite possible for the same protein to migrate as an anion at $p \mathrm{H} 9.5$ and as a cation at $p \mathrm{H} \mathrm{4.0.} \mathrm{Clearly,}$ a single system allowing the simultaneous separation of oppositely charged proteins would be desirable. To this end the method described couples two discontinuous buffer systems which provide concentrating and running conditions for both cationic and anionic proteins in the same sample.

The apparatus consisted of two separate gel tubes joined by a $3 \mathrm{~cm}$ section of clear plastic hose pierced with a small opening for the introduction of liquid sample. One gel tube contained a weak acid (taurine, $p \mathrm{~K}_{2} 8 \cdot 7$ ) and its potassium salt, while the other contained a weak base (imidazole, $p$ K 7.0) and its chloride. The sample was photo-polymerized within the plastic hose and completed the ionic connexion between the gel tubes. In principle, the doubly discontinuous system should behave in the manner described by Ornstein ${ }^{3}$. That is, there would be an initial stacking of ions in the order of fast inorganic ions followed by slower charged proteins followed by imidazole $^{+}$or taurine-. The stacking of ions towards opposite ends of the sample gel would produce sharp zones of cationic and anionic protein. Finally, these would be over-run by imidazole ${ }^{+}$or taurine- when the ion stack reached the running gel and the proteins would begin to separate on the basis of size and charge.

The gel and buffer formulations were as follows. (a) Cation running gel buffer: $1.2 \mathrm{ml} .1$ molar potassium hydroxide, $0.75 \mathrm{~g}$ taurine, $25 \mu \mathrm{l}$. tetramethylethylenediamine, made up with water to $10 \mathrm{ml}$. This system had an original $p \mathrm{H}$ of $8 \cdot 1$ and a running $p \mathrm{H}$ of 7.5. (b) Anion running gel buffer: $1.2 \mathrm{ml}$. 1 normal hydrochloric acid, $0.50 \mathrm{~g}$ imidazole, $50 \mu \mathrm{l}$. tetramethylethylenediamine, made up with water to $10 \mathrm{ml}$, giving an original $p \mathrm{H}$ of $7 \cdot 7$ and a running $p \mathrm{H}$ of 8.3 .

Running gels were formed by mixing two volumes of one of these buffer systems with two volumes of a solution of $20 \mathrm{~g}$ acrylamide, $0.8 \mathrm{~g} N, N^{\prime}$-methylbisacrylamide, $7.5 \mathrm{mg}$ potassium ferricyanide, and water to $100 \mathrm{ml}$. with four volumes of 0.14 per cent ammonium persulphate
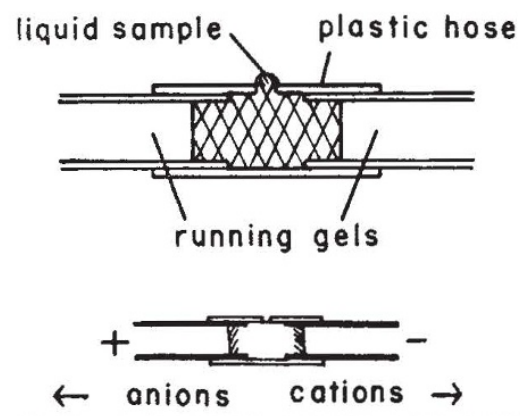

Fig. 1. Double-disc electrophoresis apparatus. Top, side view in crosssection showing the sample before polymerization. Bottom, same view during electrophoretic stacking of the sample anions and cations (shaded lines).

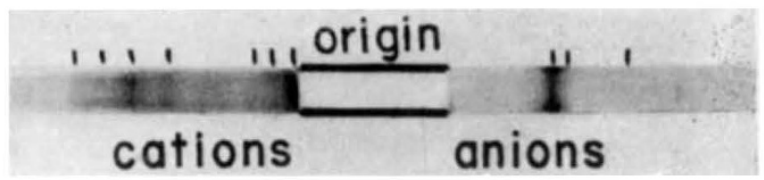

Fig. 2. Bean Ieaf peroxıdases separated by double-disc electrophoresis. The photograph is a composite to show the original running position of the gel tubes. Peroxidase zones, some of which photograph poorly, are marked by short, vertical lines.

in water. The mixture was pipetted rapidly into glass tubes $55 \mathrm{~mm}$ long and $8 \mathrm{~mm}$ in internal diameter to within $1 / 8$ in. of the top and layered carefully with water. Polymerization occurred in about $10 \mathrm{~min}$ as indicated by the formation of a refractile zone below the initial layer.

The sample gel $(c)$ contained $200 \mu l$. of water containing enough safranin $O$ and bromphenol blue to produce visible zones during electrophoresis; it also contained $150 \mu \mathrm{l}$. of 1 per cent tetramethylethylenediamine in water, $150 \mu \mathrm{l}$. of a solution containing $4 \mathrm{mg}$ of riboflavin in 100 $\mathrm{ml}$. of water, $150 \mu \mathrm{l}$. of a solution of 40 per cent acrylamide and 10 per cent $N, N^{\prime}$-methylenebisacrylamide in water, and $1.75 \mathrm{ml}$. of the sample in 0.025 molar phosphate at $p \mathrm{H} 7 \cdot 0$.

The components were quickly mixed and injected into the sample chambers, care being taken not to entrain air bubbles. In the present instance, $1 \mathrm{ml}$. of the mixture provided sufficient sample for a single analysis which was usually run in duplicate. The running gel tubes were pushed into the sample chamber so as to exclude air and to force a drop of sample up through the chamber opening (Fig. 1). A piece of plastic film was slid over the drop to scal off air and the chambers were exposed to bright fluorescent light until polymerization produced an opalescent gel. Alternatively, the sample chamber was closed by sliding in one of the gel tubes so as to cover the opening.

The units were connected vertically between two electrode boxes which were then filled with the following solutions: negative electrode box, 0.038 molar taurine and 0.0038 molar potassium hydroxide; positive electrode box, 0.038 molar imidazole and 0.0038 molar hydrochloric acid.

A typical run required about $2 \mathrm{~h}$ at $100 \mathrm{~V}$, at which time the cationic (safranin $O$ ) and anionic (bromphenol blue) marker dyes had migrated 4 to $5 \mathrm{~cm}$ into their respective tubes. The gels were removed by the usual rimming technique ${ }^{1}$ and stained for enzyme activity or protein. The analysis of bean leaf protein revealed three anionic peroxidases and seven cationic peroxidases using guaiacol and hydrogen peroxide as chromogenic substrates (Fig. 2).

Department of Agricultural Biochemistry,

Agricultural Experiment Station,

University of Vermont, Burlington, Vermont.

${ }^{1}$ Davis, B. J., Ann. N.Y. Acad. Sci.,121, 404 (1964).

${ }^{3}$ Reisfeld, R. A., Lewis, V. J., and Williams, D. E., Nature, 195, 281 (1962).

${ }^{3}$ Ornstein, L., Ann. N.Y. Acad. Sci.,121, 321 (1964). 